\title{
High risk of macrosomia in newborns of immigrant mothers
}

\author{
Mario De Curtis ${ }^{1}$, Leonardo Villani ${ }^{2^{*}}$ and Arianna Polo ${ }^{3}$
}

\begin{abstract}
Background: In Italy live about $8.7 \%$ immigrants, which contribute to more than $15 \%$ of all deliveries taking place in Italy. We aimed to investigate whether newborns from high migratory pressure countries (HMPC) mothers have a different macrosomia and post-term pregnancy incidence compared to Italian newborns.

Methods: In this retrospective observational study, we analyzed data on 404.863 babies born between 2010 and 2017. Italian mothers delivered 309.658 (76.5\%), HMPC mothers 88.179 (21.8\%) and developed country (DC) mothers 7.026 (1.7\%) babies. We analyzed the incidence of macrosomia and post term pregnancy.

We estimated incidence rate (IR), unadjusted incidence rate ratio (IRR) and 95\% confidence intervals (CIs) to evaluate the association between these perinatal parameters and the mother's region of birth.

Results: HMPC compared to Italian newborns showed a significantly higher incidence of birthweight $>4000 \mathrm{~g}$ (53.3\%o vs 39.1\%o, $p$-value $<0.001$; IRR 1.4, 95\%Cl=1.36-1.45), birthweight $\geq 4500$ g. (7.0\%o vs 3.8\%o, p-value $<0.001$; IRR $1.8,95 \% \mathrm{Cl}=1.67-2.0)$ and gestational age at birth $>41$ weeks (19.9\%o vs $12.8 \%$, $\mathrm{p}$-value $<0.001$; IRR 1.55 , $95 \% \mathrm{Cl}=1.47-1.64)$.

The macrosomia incidence between HPMC and Italian newborns was significantly increased at all gestational ages (Fig. 1), especially for mothers coming from Central Eastern Europe (121.79\% vs 91.1\%o, $p$-value< 0.001; IRR 1.34, $95 \% \mathrm{Cl}=1.11-1.62)$.
\end{abstract}

Conclusion: In Italy immigrant status represents a risk factor for macrosomia and post-term birth, which could be related to socio-economic status and unfavorable life conditions of immigrant mothers during pregnancy.

Keywords: Macrosomia, Immigrant, Inequality

\section{Main text}

In Italy live about $8.7 \%$ immigrants, which contribute to more than $15 \%$ of all deliveries taking place in Italy. This estimate substantially increases considering newborns from foreign mothers with Italian fathers [1]. Immigrant mothers encounter during gestation and delivery several problems and newborns are very often premature [2]. We aimed to investigate whether newborns from high migratory pressure countries (HMPC) mothers have a different macrosomia and post-term pregnancy incidence compared to Italian newborns.

In this retrospective observational study, we obtained data from the Lazio hospital discharge database, which records perinatal information on all newborns. The

\footnotetext{
* Correspondence: leonardovillani92@gmail.com

${ }^{2}$ Public Health Department, Università Cattolica del Sacro Cuore, Rome, Italy Full list of author information is available at the end of the article
}

Lazio Region registers each year $10 \%$ of all newborns delivered in Italy. We analyzed data on 404.863 babies born between 2010 and 2017. Italian mothers delivered 309.658 (76.5\%), HMPC mothers 88.179 (21.8\%) and developed country (DC) mothers 7.026 (1.7\%) babies. We identified eight regions of origin within the HMPC group. We analyzed the incidence of macrosomia (birth weight $>4000 \mathrm{~g}$. or $\geq 4500 \mathrm{~g}$.) and post term pregnancy ( $>41$ weeks gestational age).

We estimated incidence rate (IR), unadjusted incidence rate ratio (IRR) and 95\% confidence intervals (CIs) to evaluate the association between these perinatal parameters and the mother's region of birth. The comparison was carried out between HMPC and Italian newborns because we considered DC newborns similar to Italian babies.

(c) The Author(s). 2020 Open Access This article is distributed under the terms of the Creative Commons Attribution 4.0 International License (http://creativecommons.org/licenses/by/4.0/), which permits unrestricted use, distribution, and reproduction in any medium, provided you give appropriate credit to the original author(s) and the source, provide a link to the Creative Commons license, and indicate if changes were made. The Creative Commons Public Domain Dedication waiver (http://creativecommons.org/publicdomain/zero/1.0/) applies to the data made available in this article, unless otherwise stated. 


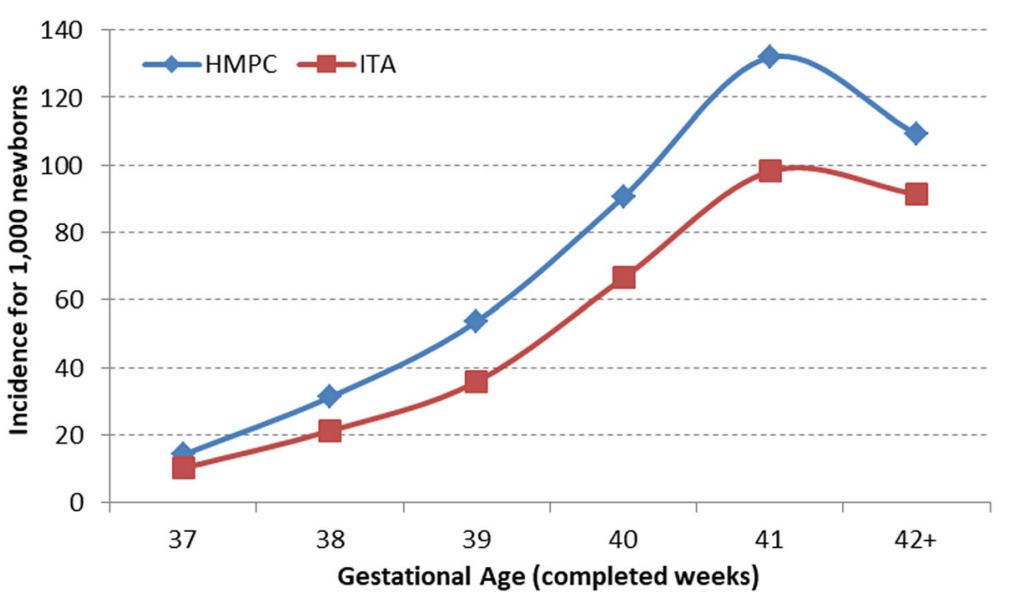

Fig. 1 Incidence of macrosomia (birthweight $>4000 \mathrm{gr}$ ) in newborns of mothers coming from high migratory pressure countries (HMPC) and infants born to Italian mothers (ITA)

HMPC compared to Italian newborns showed a significantly higher incidence of birthweight $>4000 \mathrm{~g}$ $(53.3 \%$ vs $39.1 \%$, $p$-value $<0.001$; IRR $1.4,95 \% \mathrm{CI}=$ $1.36-1.45)$, birthweight $\geq 4500$ g. (7.0\%o vs $3.8 \%$, p-value $<0.001$; IRR $1.8,95 \% \mathrm{CI}=1.67-2.0)$ and gestational age at birth > 41 weeks $(19.9 \%$ vs $12.8 \%, p$-value $<0.001$; IRR $1.55,95 \% \mathrm{CI}=1.47-1.64$ ).

The macrosomia incidence between HPMC and Italian newborns was significantly increased at all gestational ages (Fig. 1), especially for mothers coming from Central Eastern Europe $(121.79 \%$ ov $91.1 \%$, p-value $<0.001$; IRR $1.34,95 \% \mathrm{CI}=1.11-1.62$ ).

Higher obesity incidence in foreign mothers' and gestational diabetes, favorited by a high glycemic diet, possibly due to lower costs of these foods, might explain those differences [3].

In Italy immigrant status represents a risk factor for macrosomia and post-term birth, which could be related to socio-economic status and unfavorable life conditions of immigrant mothers during pregnancy.

\section{Acknowledgements}

Not applicable.

\section{Availability of data and materials' statement}

CedAP Regione Lazio.

\section{Authors' contributions}

MDC designed the study and interpreted the data. LV was a major contributor in writing the manuscript. AP extracted and analyzed data. All authors read and approved the final manuscript.

\section{Funding}

No kind of funding was recived for this research.

\section{Ethics approval and consent to participate}

Not applicable.

\section{Consent for publication}

Not applicable.

\section{Competing interests}

The authors declare that they have no competing interests.

\section{Author details}

'Maternal and Child Health Department, University of Rome La Sapienza, Piazzale Aldo Moro, 5, 00185 Rome, Italy. ${ }^{2}$ Public Health Department, Università Cattolica del Sacro Cuore, Rome, Italy. ${ }^{3}$ Direzione Salute e

Integrazione Sociosanitaria Regione Lazio, Rome, Italy.

Received: 11 December 2019 Accepted: 7 January 2020

Published online: 16 January 2020

References

1. ISTAT: Report stime per l'anno 2018. Indicatori Demografici (accessed: 07/ 2019) [https://www.istat.it/it/files//2019/02/Report-Stime-indicatoridemografici.pdf].

2. Cacciani L, Asole S, Polo A, Franco F, Lucchini R, De Curtis M, Di Lallo D, Guasticchi G. Perinatal outcomes among immigrant mothers over two periods in a region of Central Italy. BMC Public Health. 2011 Dec;11(1):294.

3. Baird J, Fisher D, Lucas P, Kleijnen J, Roberts H, Law C. Being big or growing fast: systematic review of size and growth in infancy and later obesity. BMJ. 2005 Oct 20;331(7522):929.

\section{Publisher's Note}

Springer Nature remains neutral with regard to jurisdictional claims in published maps and institutional affiliations.

Ready to submit your research? Choose BMC and benefit from:

- fast, convenient online submission

- thorough peer review by experienced researchers in your field

- rapid publication on acceptance

- support for research data, including large and complex data types

- gold Open Access which fosters wider collaboration and increased citations

- maximum visibility for your research: over $100 \mathrm{M}$ website views per year

At $\mathrm{BMC}$, research is always in progress.

Learn more biomedcentral.com/submissions 